УДК 378.001

DOI:

Іван Василиків, кандидат педагогічних наук, старший викладач кафедри математики, інформатики та методики їх викладання у початковій школі Дрогобицького державного педагогічного університету імені Івана Франка

\title{
ПРАКСЕОЛОГІЧНА СПРЯМОВАНІСТЬ ФОРМУВАННЯ ПРОФЕСІЙНОӤ ПІДГОТОВКИ МАЙБУТНІХ УЧИТЕЛІВ ПОЧАТКОВИХ КЛАСІВ
}

У статті розглядається питання професійної підготовки майбутніх учителів початкових класів, иляхи ї̈ вдосконалення та оптимізації. Було вирішено, шчо підхід, розроблений в контексті ідеї створення праксеологічного навчального середовища, має особливе значення для вдосконалення професійної підготовки майбутніх учителів початкових класів. Висвітлено сутність, зміст та структура таких педагогічних категорій, як: “праксеологічний підхід”, “праксеологія”. Дослідження розкриває сутність функиій праксеологічного підхіду та аналізує його взаємозв'язок у праксеологічному навчальному середовищі для професійного розвитку вчителів початкових класів у майбутньому. Конкретний аналіз загальнонаукових концепцій, таких як праксеологічний підхід, розглядається в контексті професійного розвиткумайбутнього вчителя початкових класів. Слід зазначити, щуо праксеологічний підхід формує та розвиває праксеологічні компетениії майбутнього вчителя початкових класів, такі як здатність планувати, організовувати та оцінювати якість своїх навчальних та професійних досягнень.

Ключові слова: професійна підготовка; праксеологія; праксеологічний підхід; загальнонаукові підходи; майбутній вчитель початкових класів.

Jim. 14.

Ivan Vasylykiv, Ph.D.(Pedagogy), Senior Lecturer of the Mathematics, Informatics and Methods of Teaching in Primary School Department, Drohobych Ivan Franko State Pedagogical University

\section{PRACTICEOLOGICAL ORIENTATION OF FORMATION OF PROFESSIONAL TRAINING OF FUTURE PRIMARY SCHOOL TEACHERS}

The article considers the issue of professional training of future primary school teachers, as well as ways to improve and optimize. The approaches are developed in the context of the idea of creating a professional educational environment, especially interested in improving the professional training of future primary school teachers. This article discusses the essence, content and structure of such teaching methods as "praxeological approach" and "praxeology". This study reveals the nature of the functions of the praxeological approach and analyzes their relationship in the educational environment of praxeology for the professional development of primary school teachers in the future. The article considers the analysis of general scientific concepts, such as human behavioral methods in the context of professional development of primary school teachers in the future. It is worth noting that the professional approach has formed and developed such important professional skills of future primary school teachers as the ability to plan, organize and evaluate the quality of their own education and professional achievements.

To consider the praxeological approach as a basis for the quality of professional training of future primary school teachers, as well as to analyze domestic and foreign literature, we concluded that the professional training of future primary school teachers is a broad and ambiguous concept that can be considered as a type of professional education. The arthor highlights the professional training of future primary school teachers. Professional training of future primary school teachers is a constant improvement of the level of professional theoretical knowledge and skills, which allows them to perform their duties in a qualified and efficient way.

Keywords: professional training; praxeology; praxeological approach; general scientific approaches; future primary school teacher.

П остановка проблеми. Інтеграційні світові процеси визначають пошук ефективних шляхів вдосконалення національних систем освіти, підвищення якості вищої освіти, оновлення та організація змісту навчання відповідно до вимог ринку праці та викликів сучасного динамічного суспільства. Важливим фактором вдосконалення навчального процесу у закладах вищої освіти є вдосконалення професійної підготовки майбутніх фахівців, у тому числі вчителів, для ефективного виконання професійної діяльності. Основою цього навчання $\epsilon$ формування готовності майбутніх учителів початкових класів до продуктивної педагогічної діяльності, яка передбачає праксеологічну складову та базується на праксеологічному підході до процесу професійного навчання. 


\section{ПРАКСЕОЛОГІЧНА СПРЯМОВАНІСТЬ ФОРМУВАННЯ ПРОФЕСІЙНОЇПІДГОТОВКИ МАЙБУТНІХУЧИТЕЛІВ ПОЧАТКОВИХ КЛАСІВ}

\begin{abstract}
Аналіз останніх досліджень і публікацій. Педагогічна наука також аналізує важливість праксеологічного підходу в освітньому процесі: зокрема, дослідження Т. Бодрової, І. Колеснікової, В. Савіцької, О. Титової та інших підкреслюють важливість праксеологічної основи у педагогічній діяльності; В. Федотова аналізує роль праксеології в процесі дослідницької діяльності студентів; О. Уточкіна визначає особливості застосування праксеологічного підходу у формуванні здатності майбутнього вчителя до професійно-педагогічної самооцінки; Н. Коробова та В. Шарко проаналізували можливості праксеологічного підходу щодо вдосконалення методичної підготовки вчителів фізики.
\end{abstract}

О. Біляковська аналізує сугність праксеологічного підходу до професійної підготовки майбутніх учителів та дослідження українських та польських вчених щодо проблеми праксеологічного підходу в системі професійної підготовки;

Є. Рябуха визначає роль і місце праксеологічної науки у вирішенні проблем підвищення якості вищої освіти; В. Федотова вивчала можливості використання праксеології в організації дослідницької діяльності студентів тощо.

Не обминули увагу дослідження важливості формування праксеологічних компетенцій у процесі підготовки майбутніх учителів до ефективної професійної діяльності зарубіжних дослідників у галузі освіти, зокрема польських науковців Cz. Banach, K. Denek, P. Ziółkowski, J. Pielachowski, W. Strykowski, J. Strykowska.

Виділення невирішених раніше частин загальної проблеми. Водночас, незважаючи на широкий спектр досліджень, впровадження праксеологічного підходу у забезпеченні якості професійної підготовки майбутніх учителів, питання залишатиметься невирішеним.

Метою дослідження є розкрити сутність праксеологічного підходу та окреслити його можливості у системі професійної підготовки майбутніх вчителів України та Польщі в контексті забезпечення іï якості.

Викладення основного матеріалу. Болонський процес в Україні, сучасні нормативно-правові документи у галузі професійної освіти, ставлять нові вимоги до якості професійної підготовки майбутніх фахівців, ініціюють формування професійної компетентності, конкурентоспроможності, готовності до практичної професійної діяльності $з$ мінімальними витратами ресурсів. Вирішення даних завдань сприяс реалізація інноваційних педагогічних підходів, одним 3 яких $\epsilon$ праксеологічний.

Виходячи 3 довідкової літератури, термін “праксеологія" походить від грецького praxis (дія, практика) або латинського praxeus (дія, діяння), що буквально означає “знання про дії". Нам імпонує визначення цього терміна, подане О. Романишиною, розглядаючи праксеологію “особливою галуззю знань, що спрямована на виявлення загальних тенденцій логіки діяльності, складова методології, що намагається теоретично узагальнити величезний досвід людства в результативній діяльності, визначає якісні характеристики діяльної особистості” $[10,56]$.

У процесі історичного розвитку педагогіки поняття “педагогічна праксеологія" виникло як результат прагнення пов'язати педагогічну картину світу з потребами педагогічної діяльності. Дуже важко визначити часові рамки народження цієї концепції, оскільки вона не була спеціально визначена педагогами-дослідниками, тому можна припустити, що обидві концепції з'явилися одночасно. На думку I. Колеснікової, наука про педагогічну практику функціонуе в системі педагогічних знань як загальна теорія педагогічної діяльності. Як галузь науки, орієнтована на практичні потреби, вона в першу чергу орієнтована на роботу вчителя загалом, участь у педагогічній діяльності $[1,12] .3$ точки зору науки педагогічної практики важливо зрозуміти суть практичної спрямованості, яка базується на підході О. Романишиної. Вчений вважає, що практична спрямованість формування професійної підготовки майбутнього спеціаліста означає, що студенти мають можливість визначати об'єктивні та суб'єктивні аспекти окремих дій, формувати в їх свідомості ідеальну форму фахівця, визначати особистісні значення по відношенню до продемонстрованого ідеалу, рівня теоретичної та практичної підготовки для оптимального ведення бізнесу [10,61]. Відповідно практична спрямованість процесу формування професійної підготовки майбутніх учителів початкових класів характеризується тим, що під час вивчення дисциплін інформатики, після оволодіння базовим рівнем компетентностей, учні мають можливість скорегувати свої навчальні досягнення.

Науковці розробили різні підходи для здійснення ефективного навчання майбутніх фахівців, включаючи праксіологічне навчання. Його реалізація розпочалась у другій половині XX ст. і має на меті вивчення людської діяльності з точки зору оптимального здійснення. Зокрема, В. Полішук доводить його значимість, підтверджуючи, що це дозволяе виявити загальні закономірності та принципи раціональної професійної діяльності, шляхи та умови підвищення ефективності 


\section{ПРАКСЕОЛОГІЧНА СПРЯМОВАНІСТЬ ФОРМУВАННЯ ПРОФЕСІЙНОӤ ПІДГОТОВКИ МАЙБУТНІХ УЧИТЕЛІВ ПОЧАТКОВИХ КЛАСІВ}

професійної діяльності та формує здатність студента “бути успішним на практиці” [7, 149].

На думку І. Мельничук, основою праксеологічного підходу є загальна “програма дій”, яка організовує діяльність викладачів та студентів, тобто їх робочі відносини, та забезпечує такі рівні аналізу: класифікація професійних дій та побудова системи понятійно-категоріального апарату; розробка ефективних нормативних систем діяльності вчителя та учнів; аналіз історії розвитку професії з точки зору їі доцільності та переваг та критичний аналіз методів, що використовуються в цій галузі, 3 метою вибору найкращих методів підготовки висококваліфікованих робітників у майбутньому [6]. Аналізуючи ці методи, ми наголошуємо, що діяльність та знання лежать в основі праксеологічного підходу, що підтверджується у висновках Н. Сацкова. Науковець вказує, що реалізація праксеологічного підходу залежить від інтеграції знань та діяльності як специфічної форми активного ставлення людини до навколишнього середовища, змістом якої $є$ певні зміни та перетворення, тобто вміння, цілевідповідність, дія $[12,203]$.

В тлумаченні терміну “праксеологічний підхід”, слід визнати, що підхід $\epsilon$ теоретично обгрунтованим праксеологічним способом реалізації певних принципів та сукупності ідей, заснованих на них. Тому ми погоджуємося 3 визначенням праксеологічного підходу у педагогіці I. Коробова, яку він розглядає як найбільш загальні принципи та методи підвищення ефективності та корисності професійних дій, закономірностей та умов для правильної та раціональної побудови вчителя, незалежно від його спеціалізації [2, 50].

У системі професійної педагогічної освіти праксеологія визначається як важлива методологічна основа встановлення особливостей здійснення правильних та ефективних дій майбутнього вчителя початкових класів.

Реалізація праксеологічного підходу базується на сукупності основних категорій праксеологічних наукових суджень для 3'ясування сутності професійної діяльності. Застосування праксеологічного підходу в навчальному процесі сприяє створенню середовища, необхідного для вирішення завдань. Так, П. Самойленко та С. Семенова на основі праксеологічного підходу підвищили ефективність навчального процесу з фізики шляхом створення середовища для ефективної (раціональної) спільної діяльності викладачів та студентів [11].

Праксеологічна спрямованість формування професійної підготовки майбутніх учителів початкових класів свідчить про те, що учні мають можливість визначати об'єктивні та суб'єктивні аспекти окремих педагогічних дій, формувати в їх свідомості ідеальну форму вчителів початкових класів, визначати особистісні цінності. Стосовно конкретного ідеалу, рівня теоретичної та практичної підготовки до виконання оптимальних педагогічних дій. Підтвердження своїх міркувань ми знаходимо у Н. Сацкова, який стверджує, що реалізація праксеологічного підходу залежить від інтеграції знань та діяльності як специфічної форми активного ставлення людини до навколишнього середовища, змістом якої є певні зміни та перетворення, тобто вміння, цілевідповідність, дія. Ці дві величини - знання та діяльність - $€$ основою праксеологічного підходу як цілеспрямованої системи принципів, що визначають загальну мету та стратегію орієнтованих праксеологічних дій та показують, як загальнолюдські знання стали безпосередньою продуктивною силою [12, С. 203].

Основними категоріями праксеологічної науки є “мета", “план”, “засіб”, “метод”, “результат”, “якість діяльності”, “раціональність”, “дієвість”, “продуктивність” [5]. Польський науковець Т. Котарбінський у низці своїх наукових праць, заснованої на аналізі людської діяльності з точки зору іiі доцільності, раціональності та розвитку, встановив предмет праксеологічної діяльності як окрему галузь наукового знання [3]. На думку дослідника, ефективність виступає як показник якості професійної підготовки та як категорія сприяє розвитку та вдосконаленню професійноосвітньої діяльності майбутніх учителів початкових класів.

Проаналізувавши сутність і предмет праксеологічної науки в різних інтерпретаціях та вимірах науки, Є. Проварова стверджує про те, що науку про праксеологію слід визначати як загальну теорію організації будь-якої діяльності, об'єктом якої є цілеспрямована і свідома праця як невід'ємна частина діяльносі; як наука про цілеспрямовані ефективні дії, що є головною ознакою повноцінної діяльності $[8,90]$. Це визначення є основним у нашому дослідженні для формування професійної компетентності майбутніх учителів початкових класів, оскільки проблема досконалості $є$ запорукою успіху. Успіх - це результат діяльності, який має зовнішнє та внутрішне позитивне оцінювання як якісний показник. Успішна діяльність трактується за таким алгоритмом: визначення мети (мети діяльності) - процесу (діяльності) результату (иіледосягнення) - оцінки (ефективності).

Успіх професійної діяльності вчителя 


\section{ПРАКСЕОЛОГІЧНА СПРЯМОВАНІСТЬ ФОРМУВАННЯ ПРОФЕСІЙНОЇППГОТОВКИ МАЙБУТНІХУЧИТЕЛІВ ПОЧАТКОВИХКЛАСІВ}

початкових класів оцінюється як ефективність педагогічної роботи. Суть роботи з праксеологічної точки зору, на думку Т. Котарбинського, полягає у свідомій зміні дійсності, досягненні певної мети за певних умов за допомогою відповідних засобів, завдяки чому існуючі умови поєднуються 3 тими, які відповідають цілі. Науковець наголошує, що для досягнення мети необхідно задіяти фактори, які забезпечать перехід від системи встановлення початкових умов до системи постановки кінцевих цілей, і відповідно здійснити такі дії: постановка цілей (постановка цілей); визначення умов, пов'язаних з реальністю $[4,785]$.

Інший польський науковець, Т. Пщоловський, також наголошував на важливості досконалості та майстерності дій, вважаючи іiі досконалою, наділяючи усіма позитивними якостями і одночасно позбавляючись від усього негативного [9].

Оскільки кожен предмет навчального процесу в ЗВО має свої цілі, специфічні характені риси. У цьому контексті доцільно визначити функції праксиологіїзгіднозЦ. Паскаль(C. Pascal)i А. Бертрам (A. Bertram), які зазначають, що праксеологічний підхід досліджує окремі форми вдосконалення, загальні для всіх видів діяльності. Пракселогічні знання - це істини, до яких людство дійшло в процесі багатовікової практики, та економічний підхід до вдосконалення дійсності $[13,479]$. Таким чином, праксеологічна спрямованість формування професійної підготовки майбутніх учителів початкових класів забезпечує:

- підготовку учнів до об'єктивної самооцінки своїх професійних досягнень;

- усвідомлення майбутніми вчителями початкових класів наявності чи відсутності деяких важливих професійних якостей, які виявляли видатні історичні постаті у педагогіці, моделюючи їхню педагогічну роботу, перевірену в процесі педагогічної практики тощо;

- переживання почуття професійної підготовки до майбутньої професійної діяльності вчителя в початковій школі;

- задоволеність реалізацією оптимальних, ефективних та успішних практичних дій у ролі вчителя початкових класів.

Праксеологічний підхід інтегрований з іншими загальнонауковими підходами, оскільки передбачає:

- цілеспрямовану професійну підготовку майбутніх фахівців з урахуванням когнітивного підходу, що дозволяє інтегрувати міждисциплінарні знання, історичний досвід педагогічної діяльності та інноваційні методи в сучасну педагогіку (комплексний та інтеграційний підходи);
- формування вмінь та навичок, необхідних студентам для виконання професійної роботи, що включає демонстрацію активності та перевірку раціональних моделей професійної діяльності (діяльнісний підхід);

- на основі рефлексивного аналізу своїх педагогічних дій (правильних і неправильних) студенти отримують теоретичний та практичний досвід успішної педагогічної діяльності (особистісний підхід);

- порівнюючи теоретичні та практичні моделі педагогічних дій, визначаючи доцільність їх використання у майбутній професійній діяльності, серед них найцінніші приклади свого професійного розвитку (аксіологічний підхід), визначити вершини (акмеологічний підхід) для професійного зростання та ідентифікації.

Таким чином, створюється освітне середовище 3 праксеологічною спрямованістю, головною особливістю якої є праксеологічна спрямованість на формування професійної підготовки майбутніх учителів початкових класів.

Оскільки ефективна педагогічна діяльність, як правило, праксеологічна, іiі сенсом є організація цілеспрямованої діяльності майбутніх учителів початкових класів, яка визначає активну пізнавальну діяльність учнів та сприятиме формуванню їх професійної підготовки. Адже практика - це об'єктивна, чуттєва форма життя соціально розвиненої людини з метою розвитку природної та соціальної реальності, а також специфічний спосіб ставлення людини до світу та його присутності в ньому $[14,246]$. Основою праксеологічної діяльності є робота, в якій людина цілеспрямовано здійснює професійні дії $з$ урахуванням соціальних вимог, цілей та інтересів.

Висновки 3 проведеного дослідження та перспективи. Таким чином, розглядаючи праксеологічний підхід як один з основних методів формування професійного успіху майбутніх учителів початкових класів, акцентуємо увагу на його здатності організовувати ефективну освітню діяльність у праксеологічному освітньому середовищі. Це забезпечує реалізацію функцій праксеологічного підходу, спрямованого на вдосконалення особистості в контексті їі соціального та професійного успіху та вирішення основних завдань у педагогічній діяльності: раціональне поєднання теорії та практики для реалізації навчальних завдань; виявлення оптимальних педагогічних умов ефективної педагогічної взаємодії всіх учасників освітнього процесу. Таким чином, розглядаючи праксеологічний підхід як основу якості професійної підготовки майбутніх учителів 


\section{ПРАКСЕОЛОГІЧНА СПРЯМОВАНІСТЬ ФОРМУВАННЯ ПРОФЕСІЙНОЇПІДГОТОВКИ МАЙБУТНІХ УЧИТЕЛІВ ПОЧАТКОВИХКЛАСІВ}

початкових класів, а також аналіз вітчизняної та зарубіжної літератури, ми дійшли висновку, що професійна підготовка майбутніх учителів початкових класів $є$ широким і багатогранним поняттям, яке можна розглядати як вид професійної освіти - спрямованої на підготовку вчителів початкових класів. Професійна підготовка майбутніх учителів початкових класів - це постійне підвищення рівня професійних теоретичних знань та навичок, що дозволяє їм кваліфіковано та ефективно виконувати свої обов'язки.

\section{ЛІТЕРАТУРА}

1. Колесникова И.А., Титова Е.З. Педагогическая праксеология: Учеб. пособие для студ. высш. пед. учеб. заведений. Москва: Издательский центр “Академия", 2005. 256 с.

2. Коробова I.В. Формування методичної компетентності майбутніх учителів фізики на засадах індивідуального підходу. Дисертація на здобуття наукового ступеня доктора педагогічних наук зі спеціальності: 13.00 .02 - теорія та методика навчання (фізика). URL: http:// www.npu.edu.ua /images/file/vidil aspirant/dicer/ $\%$ D0\%94 26.053.06/KOROBOVA.pdf.

3. Котарбинский Т. Трактат о хорошей работе; под ред. проф. Г.Х. Попова; пер. с польск. Л.В. Васильева и В.И. Соколовского. Москва: Экономика, 1975. С.16-17.

4. Котарбинський Т. Избранные произведения. Москва. Издательство иностранной литературы, $1963.911 \mathrm{c}$.

5. Малихін А.О. Сутність і принципи праксеологічного підходу в методичній підготовці майбутнього вчителя технологій. Наукові записки Тернопільського національного педагогічного університету ім. В. Гнатюка. Сер. Педагогіка. Тернопіль. 2014. № 3. С. 72-77.

6. Мельничук I.M. Формування професійної компетентності соціальних працівників у процесі поєднання практичної роботи студентів та інтерактивного навчання. Вища освіта Украӥни. Вісник Київького національного університету імені Тараса Шевченка. Серія "Сочіологія. Психологія. Педагогіка". Тематичний випуск № 3. "Вища освіта України у контексті інтеграції до європейського освітнього простору”. 2009. Додаток 4, том III (15). С. 259 266.

7. Поліщук В.А. Праксеологічний підхід як інноваційна основа вдосконалення професійної підготовки майбутніх соціальних працівників. Науковий вісник Ужгородського наџіонального університету : Серія: Педагогіка. Соціальна робота / гол. ред. І.В. Козубовська. Ужгород: Видавництво УжНУ “Говерла”, 2014. Вип. 32. C. $148-150$.

8. Проварова Є.M. Теорія і практика методичної підготовки майбутнього вчителя музики на засадах праксеологічного підходу: дис. д-ра пед. наук: 13.00.02. Національний пед. ун-т ім. М. П. Драгоманова. Київ, 2018. 502 с.

9. Пщоловский Т. Принципы совершенной деятельности: (Введение в праксеологию). Киев, Ин-т праксеологии, 1993. $271 \mathrm{c}$.

10.Романишина О.Я. Теоретичні і методичні основи формування професійної ідентичності майбутніх учителів засобами інформаційних технологій : дис. д-ра пед. наук : 13.00.04; Вінницький держ. пед. ун-т ім. М. Коцюбинського. Вінниця, 2016. 445 с.

11. Самойленко П. И., Семенова С. В. Повышение еффективности учебного процесса по физике на основе праксеологического похода. Збірник наукових праць Кам'янещь-Подільського держ. ун-ту. 2003. Вип. IX. С. 65-68.

12. Сацков Н.Я. Практический менеджмент. Методы и приемы деятельности руководителя. Донецк: Сталкер, 1998. 448 с.

13. Pascal C., Bertram R. Praxis, Ethics and Power: Developing Praxeology as a Participatory Paradigm for Early Childhood Research. European Early Childhood Education Research Journal. 2012. № 20(4). P. 477-492.

14. Reckwitz A. Toward a Theory of Social Practices: A Development in Culturalist Theorizing. European Journal of Social Theory. 2002. Vol. 5(2). P. 243-263.

\section{REFERENCES}

1. Kolesnikova, I.A. \& Titova, E.Z. (2005). Pedagogicheskaya prakseologiya: ucheb. posobie dlya stud. vyssh. ped. ucheb. zavedeniy [Pedagogical Praxeology: Textbook. manual for stud. higher. ped. educat. Establishments]. Moscov, 256 p.[in Russian].

2. Korobova, I.V. Formuvannia metodychnoi kompetentnosti maibutnikh uchyteliv fizyky na zasadakh indyvidualnoho pidkhodu [Formation of methodical competence of future physics teachers on the basis of individual approach]. Doctor's thesis. Available at: http://www.npu.edu.ua/images/file/ vidil aspirant/dicer/\%D0\%94 26.053.06/ KOROBOVA.pdf. [in Ukrainian].

3. Kotarbinskiy, T. (1975). Traktat o khoroshey rabote [A treatise on good work]. (Ed.).G.Kh. Popov; translation from Polish. L.V. Vasiliev and V.I. Sokolovsky. Moscov, pp.16 - 17.[in Russian].

4. Kotarbinskiy, T. (1963). Izbrannye proizvedeniya [Selected works]. Moscov, 911 p. [in Russian]. 


\section{ПРАКСЕОЛОГІЧНА СПРЯМОВАНІСТЬ ФОРМУВАННЯ ПРОФЕСІЙНОӤ ПДГОТОВКИ МАЙБУТНІХ УЧИТЕЛІВ ПОЧАТКОВИХ КЛАСІВ}

5. Malykhin, A.O. (2014). Sutnist i pryntsypy prakseolohichnoho pidkhodu v metodychnii pidhotovtsi maibutnoho vchytelia tekhnolohii [The essence and principles of praxeological approach in the methodological training of future teachers of technology]. Scientific notes of Ternopil Volodymyr Hnatyuk National Pedagogical University. Ser. Pedagogy. No. 3. pp. 72-77. [in Ukrainian].

6. Melnychuk, I.M. (2009). Formuvannia profesiinoi kompetentnosti sotsialnykh pratsivnykiv u protsesi poiednannia praktychnoi roboty studentiv ta interaktyvnoho navchannia [The formation of professional competence of social workers in the process of combining practical work of students and interactive learning]. Higher education in Ukraine. Bulletin of Taras Shevchenko National University of Kyiv. Series "Sociology. Psychology. Pedagogy". Thematic issue № 3. "Higher education in Ukraine in the context of integration into the European educational space. Appendix 4, Vol. III (15). pp. 259 266. [in Ukrainian].

7. Polishchuk, V.A. (2014). Prakseolohichnyi pidkhid yak innovatsiina osnova vdoskonalennia profesiinoi pidhotovky maibutnikh sotsialnykh pratsivnykiv [Praxeological approach as an innovative basis for improving the training of future social workers]. Scientific Bulletin of Uzhhorod National University: Series: Pedagogy. Social work. (Ed.). I.V. Kozubovska. Uzhhorod, Vol. 32. pp. 148-150. [in Ukrainian].

8. Provarova, Ye.M. (2018). Teoriia i praktyka metodychnoi pidhotovky maibutnoho vchytelia muzyky na zasadakh prakseolohichnoho pidkhodu [Theory and practice of methodical training of future music teachers on the basis of praxeological approach]. Doctor's thesis. Kyiv, 502 p.[in Ukrainian].

9. Pshcholovskiy, T. (1993). Printsipy sovershennoy deyatelnosti: (Vvedenie v prakseologiyu) [Principles of Perfect Action: (An Introduction to Praxeology)]. Kiev, 271 p. [in Russian].

10. Romanyshyna, O.Ia. (2016). Teoretychni i metodychni osnovy formuvannia profesiinoi identychnosti maibutnikh uchyteliv zasobamy informatsiinykh tekhnolohii [The theoretical and methodical bases of formation of professional identity of future teachers by means of information technologies]. Vinnytsia, 445 p. [in Ukrainian].

11. Samoylenko, P. I. \& Semenova, S. V. (2003). Povyshenie effektivnosti uchebnogo protsessa po fizike na osnove prakseologicheskogo pokhoda [Improving the effectiveness of the educational process in physics based on the praxeological approach]. Book of Science Forerunners Kamyanets-Podilskiy state. un-ty. Vol. IX. pp. 6568. [in Russian].

12. Satskov, N.Ya. (1998). Prakticheskiy menedzhment [Practical management]. Methods and techniques of the leader. Donetsk, 448 p. [in Russian].

13. Pascal, C. \& Bertram, A. (2012). Praxis, Ethics and Power: Developing Praxeology as a Participatory Paradigm for Early Childhood Research. European Early Childhood Education Research Journal. No. 20(4). pp. 477-492. [in English].

14. Reckwitz, A. (2002). Toward a Theory of Social Practices: A Development in Culturalist Theorizing. European Journal of Social Theory. Vol. 5(2). pp. 243-263. [in English].

Стаття надійшла до редакції 28.04.2021

\section{G58080.2658080}

"Сдине, що може направити нас до благородних думок $i$ виинків, - ие приклад великих $і$ морально чистих особистостей".

Альберт Ейнштейн один з найвизначніших ббізиків ХХ столітmя

"Усе своє життя старанно навчайся. Кожен день ставай майстернішим, ніж ти був за день до иъого, а на наступний день - майстернішим, ніж сьогодні. Вдосконалення не має кіния".

Ямиамото Тунетомо білософ, письменник

"Навіть в суспільстві двох чоловік я неодмінно знайду, чому у них повчитися. Їх достоїнства я постараюся наслідувати, а на їх недоліқахсам буду вчитися".

\section{Конббучій \\ давнъокитайський білософб}

\section{G58080.2058080}

